\title{
PENILAIAN PETANI TERHADAP MULTIFUNGSI PERTANIAN PADI SAWAH ANORGANIK DAN ORGANIK DI DESA TONUSU KECAMATAN PAMONA PUSELEMBA
}

\author{
Oleh : \\ Marianne Reynelda Mamondo(1), Silvany Annatje Taariwuan2)
}

\begin{abstract}
The purposes of this research are to find out the differences of the knowledge and assessment owned and made by inorganic and organic rice field farmers on the functions of rice field farming in terms of economic, social-cultural, and environmental aspects. Primary data is collected from rice field farmers in Tonusu Village through survey, using questionnaire and interview. 20 farmers determined as respondents through quota sampling, consist respectively of 10 farmers who applying inorganic and organic rice farming. Study is conducted by identifying the agriculture multifunctionality on the aspects of economic, socialcultural, and environment. Data is analyzed descriptively and tested with t test for 2 independent samples. Result demonstrates that there is difference of the knowledge between inorganic and organic farmers on the functions of rice field farming. The average number of functions known by inorganic respondents is $71.56 \%$, less than that of organic respondents with the value of $91.67 \%$, particularly on the functions of role of farm women, soil quality, biodiversity, the indicator of environment pollution, and food security. Besides, there is difference of the assessment made by both groups on the application of the rice field functions. The average of functions given high assessment by inorganic respondents is $27.08 \%$, less than that of organic respondents with the value of $46.04 \%$, on the functions of farmer solidarity, soil quality, biodiversity, environment pollution indicator, farming attraction, and food security. Therefore, the agriculture multifunctionality in organic rice field farming is better than that of the inorganic system.
\end{abstract}

Keywords : Multifunctionality, rice field, inorganic, organic

1) Staf Pengajar Fakultas Pertanian Universitas Kristen Tentena

2) Staf Pengajar Fakultas Ekonomi Universitas Kristen Tentena 


\section{PENDAHULUAN}

Kebijakan pembangunan pertanian konvensional yang diterapkan pemerintah Indonesia sejak akhir dekade 1960-an melalui penerapan revolusi hijau bersifat industrial, boros energi tak terbarukan, eksploitatif terhadap penggunaan sumber daya alam, dan berorientasi pada peningkatan produksi, secara khusus produksi pangan. Sebagai akibatnya petani dibuat menjadi sangat tergantung pada penggunaan bibit unggul, pupuk, dan pestisida kimia yang merusak lingkungan. Pada permulaan penggunaan, input agrokimia memang mampu meningkatkan produksi, tetapi dalam jangka panjang produktivitas lahan menurun, pencemaran lingkungan meningkat, serta risiko bahaya bagi kesehatan masyarakat dan konsumen bertambah besar (Saragih, 2008).

Semakin menipisnya persediaan bahan bakar fosil, terjadinya kenaikan harga BBM dunia dan di dalam negeri, peningkatan intensitas pencemaran dan kerusakan lingkungan pertanian,serta semakin lebarnya kesenjangan sosial dan kemiskinan di daerah perdesaan telah membuat masyarakat sadar akan dampak negatif yang ditimbulkan sistem pertanian konvensional. Kesadaran ini membuat masyarakat beralih dari pertanian anorganik ke penerapan teknologi pertanian alternatif yang ramah lingkungan, tidak membahayakan kesehatan, mampu menghemat biaya produksi dan penggunaan energi tak terbarukan, serta tetap dapat memenuhi keperluan akan pangan sebagai kebutuhan dasar manusia (Soemarno, 2010). Pertanian organik merupakan bentuk pertanian yang menghindari atau secara massal menyingkirkan penggunaan pupuk dan pestisida sintetik serta zat pengatur tumbuh (Saragih, 2008).

Praktik-praktik pertanian selalu memiliki peran dan fungsi yang saling terkait satu sama lain, yaitu antara aspek ekonomi, lingkungan, dan sosial (De Vries, 2000). Konsep keterkaitan peran dan fungsi sektor pertanian tersebut dikenal dengan konsep multifungsi pertanian (multifunctionality of agriculture) (Hanafie, 2010).

Menurut konsep multifungsi pertanian, pertanian dipandang tidak hanya dipandang sebagai penghasil produk-produk yang dapat dipasarkan untuk memenuhi kebutuhan konsumen, melainkan juga dipandang sebagai penghasil jasa-jasa lingkungan yang sifatnya tidak kelihatan (intangible) dan tidak dapat dipasarkan (non marketable) (Balai Penelitian Tanah, 2006). Jasa-jasa lingkungan tersebut meliputi fungsi lahan sawah sebagai pengendali banjir dan erosi, mitigasi gas rumah kaca, konservasi sumberdaya air, penyerap sampah organik, penyedia tempat rekreasi, penyejuk udara, pencipta keindahan panorama alam secara khusus di perdesaan, dan sebagai habitat bagi keanekaragaman hayati (Hanafie, 2010). Selain itu pertanian juga dipandang sebagai penyedia lapangan pekerjaan, penyangga ketahanan pangan, serta pelestari berbagai tradisi dan budaya masyarakat pedesaan (Irawan et al, 2004).

Penilaian masyarakat terhadap multifungsi pertanian perlu dilakukan karena kecenderungan yang terjadi ialah rendahnya pemahaman masyarakat terhadap fungsi-fungsi pertanian yang sifatnya tidak kelihatan (intangible) dan tidak dapat dipasarkan 
(non marketable) (Arifin, 2007). Masyarakat umumnya memandang pertanian hanya sebagai penghasil produk-produk yang terlihat secara nyata (tangible) dan dapat dipasarkan (marketable). Sementara itu, berbagai fungsi pertanian seperti terhadap aspek-aspek lingkungan, ekonomi, sosial, dan budaya tidak banyak diketahui, atau kalau pun diketahui cenderung diabaikan.

\section{Pemahaman}

terhadap multifungsi pertanian bermanfaat untuk menimbulkan penghargaan masyarakat terhadap sumberdaya alam dan lingkungan (Fauzi, 2006). Penghargaan terhadap sumberdaya alam dan lingkungan pada akhirnya akan mengarah pada terciptanya sistem pertanian berkelanjutan, yaitu sistem pertanian yang sangat mengutamakan integrasi harmonis antara berbagai komponen yang terlibat dan saling berinteraksi di dalam suatu ekosistem (Nurwadjedi et al, 2010). Menurut Vassalos et al (2010) sistem pertanian organik merupakan bentuk pertanian yang ramah lingkungan, menjamin pertanian berkelanjutan, dan dapat mendukung multifungsi pertanian. Pertanian organik juga berkontribusi mengurangi eksternalitas negatif yang dihasilkan pertanian anorganik dan mampu memberikan peluang peningkatan pendapatan (Alonso et al, 2006).

Desa Tonusu di Kecamatan Pamona Puselemba merupakan desa yang sebagian besar penduduknya bermata pencarian sebagai petani padi sawah. Di desa ini terdapat petanipetani yang telah menerapkan sistem pertanian padi sawah organik dengan metode System of Rice Intensification (SRI). Akan tetapi terdapat pula sekelompok petani yang masih menerapkan sistem pertanian konvensional.

Di antara kedua kelompok ini diduga terdapat penilaian yang berbeda mengenai konsep multifungsi pertanian, secara khusus pada tanaman padi sawah. Pertanian padi sawah memiliki beberapa fungsi seperti penguat kelembagaan dalam bentuk kebersamaan dan adanya peran kaum perempuan dalam berbagai aktivitas produksi tanaman, pemelihara tradisi atau budaya pedesaan, pemelihara kualitas tanah, pelestari biodiversitas, indikator terhadap pencemaran lingkungan, sebagai daya tarik terhadap kegiatan usahatani, dan penyangga ketahanan pangan. Pada kedua kelompok petani diduga terdapat perbedaan pemahaman mengenai fungsi-fungsi pertanian padi sawah tersebut, karena keputusan untuk menerapkan sistem pertanian anorganik maupun organik sangat ditentukan oleh pengetahuan setiap petani mengenai fungsi-fungsi pertanian dari aspek ekonomi, sosial budaya, maupun lingkungan.

Selain itu diduga terdapat perbedaan penilaian kedua kelompok mengenai fungsi-fungsi pertanian padi sawah bila ditinjau dari penerapan fungsi-fungsi tersebut dalam aktivitas produksi padi sawah. Sistem pertanian padi sawah anorganik dan organik diduga memberikan perbedaan pada fungsi-fungsi yang dilihat, dirasakan, atau dialami petani dalam aktivitas produksinya.

Tujuan penelitian ini ialah untuk mengetahui : 1) perbedaan pengetahuan petani padi sawah anorganik dan organik mengenai fungsi-fungsi pertanian padi sawah ditinjau dari aspek ekonomi, sosial budaya, dan lingkungan, dan 2) 
perbedaan penilaian petani padi sawah anorganik dan organik mengenai penerapan fungsi-fungsi pertanian padi sawah dari aspek ekonomi, sosial budaya, dan lingkungan.

\section{BAHAN DAN METODE}

Penelitian dilaksanakan dari Bulan Desember 2012 hingga Bulan Mei 2013 bertempat di Desa Tonusu Kecamatan Pamona Puselemba Kabupaten Poso. Jenis data yang dikumpulkan ialah data primer, yaitu data yang diperoleh secara langsung dari petani padi sawah di Desa Tonusu yang merupakan responden penelitian, melalui instrumen berupa kuisioner.

Penelitian ini menggunakan metode survei melalui : 1) wawancara dengan responden penelitian, dan 2) observasi atau pengamatan lapangan terhadap aktivitas pertanian padi sawah anorganik dan organik.

Populasi dalam penelitian ini ialah petani padi sawah di Desa Tonusu yang berjumlah 140 orang. Populasi terbagi atas 2 sub populasi, yaitu kelompok petani yang menerapkan sistem pertanian padi sawah anorganik sebanyak 120 orang dan kelompok petani padi sawah yang menerapkan sistem pertanian padi sawah organik sebanyak 20 orang. Dari setiap sub populasi diambil masing-masing sebanyak 10 petani sebagai sampel penelitian melalui metode sampling kuota, yaitu teknik sampling nonprobabilitas di mana ukuran sampel pada setiap sub populasi ditentukan sendiri oleh peneliti sampai pada jumlah tertentu tanpa acak (Somantri dan Muhidin, 2006). Dengan demikian jumlah sampel atau responden penelitian ditetapkan sebanyak 20 orang.

Tahap awal kajian ialah mengidentifikasi multifungsi pertanian padi sawah yang meliputi aspek ekonomi, sosial budaya, dan lingkungan. Data yang terkumpul melalui kuisioner penelitian selanjutnya dianalisis secara deskriptif dan diuji lanjut dengan uji $t \quad 2$ sampel independen. Rumus yang digunakan ialah :

$\mathrm{t}=\frac{\overline{\mathrm{x}}_{1}-\overline{\mathrm{x}}_{2}}{\sqrt{\frac{\left(\mathrm{n}_{1}-\mathrm{n}_{2}\right) \mathrm{s}_{1}^{2}+\left(\mathrm{n}_{2}-1\right) \mathrm{s}_{2}^{2}}{\mathrm{n}_{1}+\mathrm{n}_{2}-2}\left(\frac{1}{\mathrm{n}_{1}}+\frac{1}{\mathrm{n}_{2}}\right)}}$

(Somantri dan Muhidin, 2006)

Apabila $t$ hitung lebih besar daripada $t$ tabel pada taraf signifikansi $(\alpha)=0,05$ maka $\mathrm{H}_{0}$ ditolak dan $\mathrm{H}_{1}$ diterima.

Hipotesis yang akan diuji ialah :

1. Untuk tujuan penelitian 1) :

$\mathrm{H}_{0}$ : Tidak terdapat perbedaan pengetahuan petani padi sawah yang menerapkan sistem pertanian anorganik dan organik mengenai fungsi-fungsi pertanian padi sawah ditinjau dari aspek ekonomi, sosial budaya, dan lingkungan

$\mathrm{H}_{1}$ : Terdapat perbedaan pengetahuan petani padi sawah yang menerapkan sistem pertanian anorganik dan organik mengenai fungsi-fungsi pertanian padi sawah ditinjau dari aspek ekonomi, sosial budaya, dan lingkungan

2. Untuk tujuan penelitian 2) :

$\mathrm{H}_{0}$ : Tidak terdapat perbedaan penilaian petani padi sawah anorganik dan organik mengenai fungsi-fungsi 
pertanian padi sawah dari aspek ekonomi, sosial budaya, dan lingkungan

$\mathrm{H}_{1}$ : Terdapat perbedaan penilaian petani padi sawah anorganik dan organik mengenai fungsi-fungsi pertanian padi sawah dari aspek ekonomi, sosial budaya, dan lingkungan
HASIL DAN PEMBAHASAN

Pengetahuan Petani Mengenai Fungsi-fungsi Pertanian Padi Sawah

Hasil analisis mengenai pengetahuan petani tentang fungsifungsi pertanian padi sawah diperlihatkan pada Tabel 1 sebagai berikut :

Tabel 1. Pengetahuan Petani Mengenai Fungsi-fungsi Pertanian Padi Sawah

\begin{tabular}{|c|c|c|c|c|}
\hline \multirow[t]{2}{*}{ Fungsi } & \multicolumn{2}{|c|}{ Ya } & \multicolumn{2}{|c|}{ Tidak } \\
\hline & $A(\%)$ & $\mathrm{O}(\%)$ & $A(\%)$ & $\mathrm{O}(\%)$ \\
\hline \multicolumn{5}{|l|}{ 1. Kebersamaan } \\
\hline Rata-rata & 90,00 & 85,00 & 10,00 & 15,00 \\
\hline \multicolumn{5}{|l|}{ 2. Peran Wanita Tani } \\
\hline Rata-rata & 56,67 & 93,33 & 43,33 & 6,67 \\
\hline \multicolumn{5}{|l|}{ 3. Pemelihara Tradisi / Budaya } \\
\hline Rata-rata & 95,00 & 97,50 & 5,00 & 2,50 \\
\hline \multicolumn{5}{|l|}{ 4. Kualitas Tanah } \\
\hline Rata-rata & 65,00 & 92,50 & 35,00 & 7,50 \\
\hline \multicolumn{5}{|l|}{ 5. Biodiversitas / Keragaman Hayati } \\
\hline Rata-rata & 33,33 & 90,00 & 66,67 & 10,00 \\
\hline \multicolumn{5}{|l|}{ 6. Indikator Pencemaran Lingkungan } \\
\hline Rata-rata & 72,50 & 92,50 & 27,50 & 7,50 \\
\hline \multicolumn{5}{|l|}{ 7. Daya Tarik Usahatani } \\
\hline Rata-rata & 85,00 & 92,50 & 15,00 & 7,50 \\
\hline \multicolumn{5}{|l|}{ 8. Ketahanan Pangan } \\
\hline Rata-rata & 75,00 & 90,00 & 25,00 & 10,00 \\
\hline Rata-rata untuk Keseluruhan Fungsi & 71,56 & 91,67 & 28,44 & 8,33 \\
\hline $\begin{array}{r}\text { t hitung } \\
\text { t tabel pada } \alpha=0.025 \text { dan dk }=18\end{array}$ & 91 & 21 & 91 & \\
\hline
\end{tabular}

Keterangan :

A $=$ Anorganik

$\mathrm{O}=$ Organik

Tabel 1 memperlihatkan bahwa pada pertanian padi sawah anorganik, rata-rata jumlah fungsi pertanian padi sawah yang diketahui oleh responden ialah sebesar $71,56 \%$ sedangkan pada pertanian padi sawah organik diperoleh rata-rata jumlah fungsi sebesar $91,67 \%$. Nilai t hitung yang diperoleh ialah sebesar 91,41 , sedangkan nilai $\mathrm{t}$ tabel pada pada $\alpha / 2=0,05 / 2=0,025$ dan derajat kebebasan $=18$ ialah 2,101. Karena nilai $t$ hitung lebih besar daripada $t$ tabel maka $\mathrm{H}_{0}$ ditolak dan $\mathrm{H}_{1}$ diterima. Dengan demikian terdapat perbedaan pengetahuan petani padi sawah yang menerapkan sistem pertanian anorganik dan organik mengenai 
fungsi-fungsi pertanian padi sawah ditinjau dari aspek ekonomi, sosial budaya, dan lingkungan.

Tabel 1 juga memperlihatkan bahwa terdapat beberapa fungsi pertanian padi sawah yang perbedaan persentasenya cukup besar (lebih dari $10 \%$ antara kedua kelompok responden. Fungsi-fungsi tersebut meliputi peran wanita tani, kualitas tanah, biodiversitas, indikator pencemaran lingkungan, dan ketahanan pangan.

Pada pertanian padi sawah anorganik, rata-rata jumlah fungsi peran wanita tani yang diketahui oleh responden ialah sebesar 56,67 \% sedangkan pada pertanian padi sawah organik diperoleh rata-rata sebesar $93,33 \%$ Hal ini berarti bahwa kelompok petani padi sawah organik lebih mengetahui bahwa pertanian padi sawah dapat meningkatkan peran wanita tani melalui keterlibatannya dalam kegiatan usahatani, pengambilan berbagai keputusan dalam pengelolaan usahatani, dan keikutsertaan wanita tani pada berbagai organisasi yang bergerak di bidang pertanian padi sawah seperti kelompok tani wanita.

Rata-rata jumlah fungsi kualitas tanah yang diketahui oleh responden dari kelompok petani padi sawah anorganik ialah 65,00 \% sedangkan pada responden dari kelompok petani padi sawah organik diperoleh rata-rata jumlah fungsi $92,50 \%$. Artinya ialah kelompok petani padi sawah organik lebih memiliki pengetahuan mengenai fungsi pertanian padi sawah yang dapat meningkatkan kualitas tanah dalam hal kemudahan melakukan pengolahan tanah, kemudahan tanah mengering karena adanya sistem drainase, semakin dalamnya lapisan olah tanah, dan keberadaan hewanhewan kecil penyubur tanah seperti cacing tanah.

Ditinjau dari fungsi biodiversitas, rata-rata jumlah fungsi yang diketahui oleh responden dari kelompok petani padi sawah anorganik ialah sebesar $33,33 \%$ sedangkan pada responden dari kelompok petani padi sawah organik diperoleh rata-rata jumlah fungsi sebesar 90,00\%. Perbedaan persentase ini menunjukkan bahwa kelompok petani padi sawah organik lebih mengetahui fungsi pertanian padi sawah sebagai habitat bagi keanekaragaman hayati melalui keberadaan jenis gulma atau tumbuhan liar di sekitar areal pertanaman, keberadaan berbagai spesies serangga, hama, dan musuh alami.

Fungsi indikator pencemaran lingkungan memperlihatkan perbedaan persentase rata-rata jumlah fungsi yang diketahui oleh kedua kelompok responden, di mana pada kelompok petani padi sawah anorganik diperoleh rata-rata sebesar $72,50 \%$ dan pada kelompok petani padi sawah organik rata-ratanya ialah sebesar $92,50 \%$. Hal ini berarti kelompok petani padi sawah organik memiliki pengetahuan yang lebih besar mengenai fungsi lahan sawah sebagai indikator terjadinya pencemaran lingkungan oleh berbagai polutan. Lahan sawah merupakan habitat bagi hewan-hewan indikator polusi seperti katak, tikus, dan hewan-hewan kecil lainnya yang hidup dalam air. Berkurangnya kuantitas hewan-hewan tersebut menunjukkan tingkat polusi yang tinggi pada ekosistem lahan sawah.

Dari sisi fungsi ketahanan pangan, juga diperoleh perbedaan rata-rata jumlah fungsi yang diketahui 
oleh kedua kelompok responden. Pada kelompok petani padi sawah anorganik, rata-rata jumlah fungsi ketahanan pangan yang diketahui ialah $75,00 \%$, sedangkan pada kelompok petani padi sawah organik rata-rata tersebut ialah sebesar $90,00 \%$. Artinya ialah bahwa responden dari kelompok petani padi sawah organik lebih mengetahui bahwa pertanian padi sawah juga memiliki fungsi menciptakan ketahanan pangan bagi masyarakat melalui tersedianya beras sebagai bahan pangan pokok serta meningkatkan kemampuan masyarakat untuk memperoleh dan mengonsumsi bahan-bahan pangan lainnya sebagai sumber protein hewani, seperti daging, telur, dan ikan.

Berdasarkan hasil analisis dapat dijelaskan bahwa pertanian padi sawah organik telah memperluas wawasan petani mengenai fungsi pertanian padi sawah. Pada pertanian organik, usahatani padi sawah tidak lagi hanya dipandang oleh petani sebagai sumber pendapatan atau mata pencarian semata-mata. Pertanian organik telah membuka cakrawala berpikir petani bahwa lahan sawah yang dikelola juga memiliki fungsi-fungsi yang berkaitan dengan aspek sosial kemasyarakatan dan kelestarian lingkungan.

Menurut Saragih (2008), pertanian organik mengedepankan hubungan yang harmonis antar unsurunsur yang ada di alam. Pertanian organik dapat menjadi solusi yang secara langsung menggantikan revolusi hijau untuk menyediakan pangan dan penghidupan secara berkelanjutan, serta mampu memperbaiki kerusakan lingkungan yang terjadi akibat penerapan revolusi hijau. Dengan demikian pertanian organik mendorong perbaikan kualitas sumberdaya alam serta kualitas sumberdaya manusia, terutama petani yang berperan sebagai produsen bahan pangan dan pengelola usahatani.

Penilaian Petani Mengenai
Penerapan Fungsi-fungsi Pertanian
Padi Sawah
Hasil analisis mengenai
penilaian petani terhadap penerapan
fungsi-fungsi pertanian padi sawah dari
aspek ekonomi, sosial budaya, dan
lingkungan dalam akitivitas produksi
padi sawah diperlihatkan pada Tabel 2
sebagai berikut.


Tabel 2. Penilaian Petani Mengenai Penerapan Fungsi-fungsi Pertanian Padi Sawah

\begin{tabular}{|c|c|c|c|c|c|c|c|}
\hline \multirow{3}{*}{ No. } & \multirow{3}{*}{ Jenis Fungsi } & \multicolumn{6}{|c|}{ Penilaian } \\
\hline & & \multicolumn{2}{|c|}{ Tinggi } & \multicolumn{2}{|c|}{ Sedang } & \multicolumn{2}{|c|}{ Rendah } \\
\hline & & A (\%) & $\begin{array}{l}0 \\
(\%)\end{array}$ & $\begin{array}{c}A \\
(\%)\end{array}$ & $\begin{array}{l}0 \\
(\%)\end{array}$ & $\begin{array}{c}A \\
(\%)\end{array}$ & $\begin{array}{l}0 \\
(\%)\end{array}$ \\
\hline \multicolumn{8}{|c|}{ 1. Kebersamaan } \\
\hline & 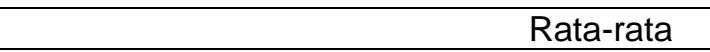 & 20,00 & 47,50 & 42,50 & 27,50 & 37,50 & 25,00 \\
\hline \multicolumn{8}{|c|}{ 2. Peran Wanita Tani } \\
\hline \multirow{2}{*}{\multicolumn{8}{|c|}{ 3. Pemelihara Tradisi / Budaya }} \\
\hline & & & & & & & \\
\hline & $\mathrm{Ra}$ & 30,00 & 37,50 & 53,33 & 47,50 & 16,67 & 15,00 \\
\hline \multicolumn{8}{|c|}{ 4. Kualitas Tanah } \\
\hline & Rata-rata & 20,00 & 67,50 & 52,50 & 22,50 & 27,50 & 10,00 \\
\hline \multicolumn{8}{|c|}{ 5. Biodiversitas / Keragaman Hayati } \\
\hline & Rata-rata & 40,00 & 63,34 & 40,00 & 13,33 & 20,00 & 23,33 \\
\hline \multicolumn{8}{|c|}{ 6. Indikator Pencemaran Lingkungan } \\
\hline & Rata-rata & 37,50 & 57,50 & 35,00 & 22,50 & 27,50 & 20,00 \\
\hline \multicolumn{8}{|c|}{ 7. Daya Tarik Usahatani } \\
\hline \multirow{2}{*}{\multicolumn{8}{|c|}{ 8. Ketahanan Pangan }} \\
\hline & & & & & & & \\
\hline & Rata-rata & 22,50 & 35,00 & 50,00 & 62,50 & 27,50 & 2,50 \\
\hline & Rata-rata untuk Keseluruhan Fungsi & 27,08 & 46,04 & 44,17 & 33,23 & 28,75 & 20,73 \\
\hline & $\begin{array}{r}\text { t hitung } \\
\text { t tabel pada } \alpha=0,025 \text { dan dk }=18\end{array}$ & 86 & 18 & $\frac{4 \mathrm{~S}}{2,1}$ & & & \\
\hline
\end{tabular}

Keterangan :

A $\quad=$ Anorganik

$\mathrm{O}=$ Organik

Tabel 2 memperlihatkan bahwa rata-rata penerapan fungsi pertanian padi sawah yang diberikan penilaian tinggi oleh responden dari kelompok petani padi sawah anorganik ialah sebesar $27,08 \%$, sedangkan pada responden dari kelompok petani padi sawah organik, rata-rata tersebut ialah sebesar 46,04 \%. Rata-rata penerapan fungsi yang diberikan penilaian sedang dari kedua kelompok responden ialah masing-masing 44,17 $\%$ pada petani padi sawah anorganik dan $33,23 \%$ pada petani padi sawah organik. Adapun rata-rata penerapan fungsi yang diberikan penilaian rendah ialah masing-masing 28,75 \% pada petani padi sawah anorganik dan 20,73 $\%$ pada petani padi sawah organik.

Nilai $\mathrm{t}$ hitung untuk penilaian pada kategori tinggi ialah 86,18 , pada kategori sedang 49,73, dan pada kategori rendah 36,45 . Nilai $t$ tabel pada taraf signifikansi $(\alpha)=0,05 / 2=$ 0,025 dan derajat kebebasan $=18$ ialah 2,101. Karena nilai t hitung lebih besar daripada t tabel maka $\mathrm{H}_{0}$ ditolak dan $\mathrm{H}_{1}$ diterima. Dengan demikian terdapat perbedaan penilaian petani padi sawah anorganik dan organik mengenai fungsi-fungsi pertanian padi sawah dari aspek ekonomi, sosial budaya, dan lingkungan.

Tabel 2 juga memperlihatkan bahwa terdapat beberapa penerapan fungsi pertanian padi sawah yang diberikan penilaian tinggi dan perbedaan persentasenya cukup besar $(\geq 10 \%)$ antara kedua kelompok 
responden. Fungsi-fungsi tersebut meliputi kebersamaan, kualitas tanah, biodiversitas, indikator pencemaran lingkungan, daya tarik usahatani, dan ketahanan pangan.

Responden dari kelompok petani padi sawah organik memberikan penilaian tinggi bagi penerapan fungsi kebersamaan dengan rata-rata sebesar 47,50 \%, lebih tinggi dibandingkan kelompok petani padi sawah anorganik dengan rata-rata hanya sebesar $20,00 \%$ Hal ini menandakan bahwa pada pertanian padi sawah organik terdapat nilai-nilai kebersamaan yang jauh lebih nyata dibandingkan pertanian padi sawah anorganik. Nilai-nilai kebersamaan tersebut meliputi gotong royong dalam kegiatan-kegiatan usahatani, adanya keaktifan anggota dalam pertemuanpertemuan kelompok tani, adanya kebutuhan secara bersama-sama terhadap informasi pertanian, dan adanya keterlibatan setiap anggota dalam kegiatan-kegiatan kelompok tani.

Pada fungsi kualitas tanah, responden dari kelompok petani padi sawah organik memberikan penilaian tinggi dengan rata-rata sebesar 67,50 $\%$, lebih tinggi dibandingkan kelompok petani padi sawah anorganik dengan rata-rata sebesar $20,00 \%$. Ini berarti bahwa pada pertanian organik petani merasakan berbagai kemudahan yang berkaitan dengan kualitas tanah sawah yang diolah. Tanah lebih mudah diolah, tanah lebih mudah mengering karena sistem drainase tanah yang baik, kedalaman lapisan olah tanah yang memungkinkan tumbuhnya perakaran tanaman secara optimal, serta keberadaan hewan-hewan penyubur tanah seperti cacing tanah yang meningkatkan kesuburan tanah secara biologis.

Untuk fungsi biodiversitas, responden dari kelompok petani padi sawah organik memberikan penilaian tinggi dengan rata-rata sebesar 63,34 $\%$, sedangkan pada kelompok petani padi sawah organik rata-ratanya hanya sebesar 40,00\%. Perbedaan rata-rata tersebut menunjukkan bahwa petani padi sawah organik telah menyadari bahwa lahan sawah merupakan sumber keanekaragaman hayati melalui keberadaan berbagai jenis gulma atau tumbuhan liar, serangga, hama, dan predator alami. Keberadaan lahan sawah juga disadari telah memungkinkan terjadinya ledakan serangan hama sebagai bagian dari proses kehidupan yang terjadi di dalam ekosistem sawah.

Responden pada kelompok petani padi sawah organik memberikan penilaian tinggi pada penerapan fungsi indikator pencemaran lingkungan dengan rata-rata sebesar $57,50 \%$, sedangkan pada kelompok petani padi sawah anorganik hanya diperoleh ratarata sebesar $37,50 \%$ Hal ini menunjukkan bahwa pada kelompok petani padi sawah organik telah berkembang suatu pemahaman bahwa lahan sawah dapat menjadi indikator pencemaran lingkungan melalui keberadaan hewan-hewan seperti katak, tikus, hewan-hewan kecil yang hidup di air, dan bahan-bahan polutan yang terlarut dalam air sawah.

Untuk fungsi daya tarik usahatani, responden dari kelompok petani padi sawah memberikan penilaian tinggi dengan rata-rata 50,00 $\%$, sedangkan pada kelompok petani padi sawah anorganik diperoleh ratarata $40,00 \%$. Bagi petani padi sawah organik, usahatani padi sawah dinilai 
sebagai sumber pendapatan dan mampu mempertahankan minat untuk bermata pencarian sebagai petani padi. Usahatani padi sawah juga dinilai sebagai lapangan pekerjaan, baik bagi petani dan keluarganya maupun bagi tenaga kerja yang berasal dari luar keluarga petani. Satu-satunya komponen dalam fungsi daya tarik usahatani yang diberikan penilaian tinggi oleh kelompok petani padi sawah anorganik (rata-rata 50,00 $\%$ ) ialah fungsi pertanian padi sawah sebagai akses memperoleh fasilitas berupa bibit, pupuk, pestisida, alat, dan mesin-mesin pertanian. $\mathrm{Hal}$ ini dikarenakan sarana produksi terutama berupa pupuk dan pestisida merupakan bahan-bahan siap pakai yang tersedia di toko-toko tani terdekat. Berbeda dengan petani padi sawah organik yang harus membuat sendiri pupuk dan pestisida alami yang membutuhkan waktu dan proses yang lebih panjang sebelum digunakan pada tanaman.

Pada fungsi ketahanan pangan, responden dari kelompok petani padi sawah organik juga memberikan penilaian tinggi dengan rata-rata sebesar 35,00 \%, lebih tinggi dibandingkan dengan rata-rata penilaian oleh kelompok petani padi sawah organik sebesar $22,50 \%$. Perbedaan persentase ini terutama disebabkan karena petani padi sawah organik menyadari bahwa usahatani padi sawah yang mereka lakukan merupakan akses bagi kecukupan beras sebagai bahan pangan pokok keluarga dan juga akses bagi kemudahan memperoleh beras sebagai kebutuhan pangan harian keluarga.

Pada fungsi peran wanita tani dan pemelihara tradisi, penilaian yang diberikan oleh kedua kelompok responden memiliki perbedaan yang tidak lebih dari $10 \%$ Hal ini menunjukkan bahwa pada kedua kelompok responden, peran wanita tani masih belum dominan dalam hal keterlibatan pada usahatani, pengambilan keputusan mengenai pengelolaan usahatani, dan keterlibatan wanita dalam organisasiorganisasi pertanian. Kedua kelompok juga memiliki penilaian yang perbedaannya tidak melebihi $10 \%$ mengenai penerapan fungsi pertanian padi sawah sebagai pemelihara tradisi atau budaya perdesaan. Pertanian padi sawah dianggap mampu memelihara tradisi yang sudah berlangsung secara turun-temurun, di antaranya budaya mesale atau kerja sama kelompok untuk kegiatankegiatan tertentu seperti penanaman atau panen padi. Tradisi lain yang ikut dilestarikan ialah berupa pesta pengucapan syukur tahunan atau padungku yang diadakan oleh masyarakat sesudah selesainya panen padi.

Berdasarkan uraian tersebut maka dapat dikatakan bahwa penerapan sistem pertanian padi sawah organik memberikan lebih banyak manfaat positif bagi pembentukan wawasan, pengetahuan, dan penguatan kelembagaan bagi petani. Wilson (2007) menyatakan bahwa derajat multifungsi pertanian dikatakan tinggi jika suatu usaha pertanian tidak hanya mementingkan produktivitas yang tinggi, tetapi juga memperlihatkan karakteristik berupa pemeliharaan lingkungan, kelestarian tradisi atau budaya masyarakat, kehidupan sosial kemasyarakatan yang erat, dan kemudahan akses untuk memperoleh bahan pangan. 
Dengan demikian pada studi ini diperoleh bahwa multifungsi pertanian pada sistem pertanian padi sawah organik lebih tinggi dibandingkan dengan pada sistem pertanian padi sawah anorganik.

\section{KESIMPULAN}

Kesimpulan yang dapat diambil dari penelitian ini ialah :

1. Petani padi sawah organik memiliki pengetahuan yang lebih tinggi dibandingkan petani padi sawah anorganik mengenai fungsi-fungsi pertanian padi sawah yang meliputi peran wanita tani, kualitas tanah, biodiversitas, indikator pencemaran lingkungan, dan ketahanan pangan.

2. Petani padi sawah organik memberikan penilaian tinggi terhadap penerapan fungsi-fungsi pertanian padi sawah yang meliputi kebersamaan, kualitas tanah, biodiversitas, indikator pencemaran lingkungan, daya tarik usahatani, dan ketahanan pangan.

3. Multifungsi pertanian pada sistem pertanian padi sawah organik lebih tinggi dibandingkan dengan pada sistem pertanian padi sawah anorganik.

\section{DAFTAR PUSTAKA}

Alonso, M., M.Antonio, I. Mudarra, M.D.Domingues, J. Molero, and I. Banda, 2006. Productive and Institutional Multifunctionality : Organic Farming in Protected Areas. Presented at XXI Congress of European Society for Rural Sociology (Working Group 25 : The Construction of
Regulating Policies for Multifunctional Agriculture).

Arifin, B., 2007. Diagnosis Ekonomi Politik Pangan dan Pertanian. Raja Grafindo Persada. Jakarta.

Balai Penelitian Tanah, 2006. Konsep Multifungsi untuk Revitalisasi Pertanian. Warta Penelitian dan Pengembangan Pertanian Volume 28 Nomor 25. ISSN 0216 $-4427$.

De Vries, B., 2000. Multifunctional Agriculture in the International Context : A Review. The Land Stewardship Project.

Fauzi, A., 2006. Ekonomi Sumberdaya Alam dan Lingkungan : Teori dan Aplikasi. Gramedia Pustaka Utama. Jakarta.

Hanafie, R., 2010. Pengantar Ekonomi Pertanian. Andi Offset. Yogyakarta.

Irawan, Husen, Maswar, R.L. Watung, dan F. Agus, 2004. Persepsi dan Apresiasi Masyarakat Terhadap Multifungsi Pertanian : Studi Kasus di Jawa Barat. Prosiding Seminar Multifungsi Pertanian dan Konservasi Sumberdaya Lahan, Bogor, 18 Desember 2003 dan Januari 2004 . Pusat Penelitian dan Pengembangan Tanah dan Agroklimat, Bogor.

Nurwadjedi, B. Mulyanto, S. Sabiham, A. Poniman, Suwardi, 2010. Indeks Keberlanjutan Lahan Sawah untuk Mendukung Penataan Ruang (Studi Kasus di Kabupaten Jember, Jawa Timur). 
Jurnal Tanah dan Iklim Volume10 Nomor 32 Tahun 2010. ISSN $1410-7244$.

Saragih, S.E., 2008. Pertanian Organik : Solusi Hidup Harmoni dan Berkelanjutan. Penebar Swadaya. Jakarta.

Somantri, A. dan S.A. Muhidin, 2006. Aplikasi Statistika dalam Penelitian. Pustaka Setia, Bandung.

Soemarno, 2010. Metode Valuasi Ekonomi Sumberdaya Lahan Pertanian. Bahan Kajian Matakuliah Ekonomi Sumberdaya Alam. Program Pasca Sarjana Universitas Brawijaya. Malang.

Vassalos, M., C.R. Dillon, D. Freshwater, and P. Karanikolas, 2010. Farm Decision-Making in a Multifunctional Context : The Case of Conventional and Organic Farming in Kerkini District. Greece.

Wilson, G.A., 2007. Multifunctional Agriculture : A Transition Theory Perspective. CAB International. Wallingford. 